https://doi.org/10.5817/OS2020-2-11

\title{
Tematický slovník češtiny, bulharštiny, srbštiny a chorvatštiny
}

KREJČOVÁ, E., PETROV, A., STEHLÍKOVÁ ĐURASek, M.: Tematický slovník češtiny, bulharštiny, srbštiny a chorvatštiny. Brno: Masarykova univerzita, 2019. 169 s. ISBN 978-80-210-9336-2.

Tematický slovník troch juhoslovanských jazykov a češtiny je učebnou pomôckou nielen pre študentov balkanistických oborov, ale aj samoukov alebo lektorov. Sústreduje sa na základnú slovnú zásobu (A2 až B1 podla SERR). Vznikol medzinárodnou spoluprácou troch jeho autoriek, z ktorých dve pôsobia na Masarykovej univerzite (E. Krejčová, M.Stehlíková Đurasek) a tretia, A. Petrov, na univerzite v Toronte. Jednotlivé heslá sú v slovníku zobrazené vel’mi prakticky. Český výraz je uvádzaný v lavom stl̂pci nasledovaný bulharčinou, srbčinou a chorvátčinou (v tomto poradí). 21 kapitol je rozdelených podla sémantických hniezd (dom, rodina, čas a počasie, volný čas a zábava, práca, školstvo, ludské telo, potraviny a stravovanie, mesto a dedina, komunikácia, obchod a služby, doprava a cestovanie, umenie a kultúra, štát a spoločnost', ekonomika, viera a náboženstvo, Zem, rastliny, živočíchy, životné prostredie a ekológia, vesmír). Každá kapitola (napr. dom) sa dalej delí na podkapitoly (napr. dom a byt), vybrané slová (napr. byt) a ich atribúty (napr. hladat nový, dvojizbový atd.).

Tematický slovník je dobrou pomôckou pri učení a orientovaní sa v základnej slovnej zásobe. V prípade, že študent (či samouk) siahne po slovníku, ked' už jedným zo spomínaných jazykov hovorí, ulahčí mu to učenie sa nových slov. Jednoduché rozloženie do stĺpcov a tematické usporiadanie hesiel umožňuje okamžité porovnávanie slov bez nutnosti listovat’ medzi jednotlivými jazykovými častami. Mierne pokročilý používatel' ocení možnost’ naučit’ sa nové výrazy spájajúce sa so základnými slovami, ktoré sú mu už pravdepodobne známe z predchádzajúceho štúdia. Pre záujemcov o juhoslovanské jazyky môže byt’ cenným prostriedkom na porovnanie slovnej zásoby uvedených jazykov. Oceňujem velmi vyčerpávajúcu 5. kapitolu Práce (s. 50 - 55) a zároveň chcem vyzdvihnút použitie mužského aj ženského variantu pri povolaniach. Študent sa tak môže rovno naučit’ obidva tvary a nemusí si ich odvodzovat’ či prácne hladat'.

Jeho kvalitu neznižujú ani miestami chýbajúce výrazy, ktoré by mohli byt tiež užitočné pre túto jazykovú úroveň. Napríklad pri hesle byt (s. 11) chýba slovné spojenie prenajat' si. Čast' Stavební materiál, technické vybavení (s. 20) by si v budúcom vydaní zaslúžila rozšírenie o bežne používané nástroje ako napr. klinec či kladivo. Podkapitola 
Hobby a koníčky (s. 46) sa z nejakého dôvodu obmedzuje len na zberatelstvo a rybačku, hoci by sa dali pridat aj dalšie ako napr. pletenie, varenie, fotografovanie atd. V podkapitole Počitač, internet a další zpưsoby komunikace (s. 98 -99) autorkám ušlo užitočné heslo pre sociálne siete, ktoré by si v slovníku a v sekcii o modernej komunikácii isto našlo svoje miesto. Prekvapivo však v celom slovníku absentuje čast̉ o štátoch a štátnych príslušníkoch, čo sú slová, s ktorými začiatočníci prichádzajú do kontaktu pomerne skoro.

Tematický slovník vel'mi užitočnou pomôckou, ktorú využijú a ocenia nielen študenti či záujemcovia o juhoslovanské jazyky, ale aj učitelia, prekladatelia a autori učebníc. Je to dobrým rámcom základnej slovnej zásoby a v budúcnosti sa snád dočká rozšírenia napr. o slovinčinu či macedónčinu.

Dominika Kubišová

\section{Literatúra:}

KREJČOVÁ, E., PETROV, A., STEHLÍKOVÁ ĐURASek, M.: Tematický slovník češtiny, bulharštiny, srbštiny a chorvatštiny. Brno: Masarykova univerzita, 2019. $169 \mathrm{~s}$. ISBN 978-80-210-9336-2.

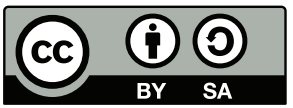

This work can be used in accordance with the Creative Commons BY-SA 4.0 International license terms and conditions (<https://creativecommons.org/licenses/by-sa/4.0/legalcode>). This does not apply to works or elements (such as images or photographs) that are used in the work under a contractual license or exception or limitation to relevant rights. 